\title{
Hakekat Keadaan Darurat Negara (State Of Emergency) sebagai Dasar Pembentukan Peraturan Pemerintah Pengganti Undang-Undang
}

\author{
Muhammad Syarif Nuh \\ Fakultas Hukum Universitas Muslim Indonesia \\ Jl. Urip Sumoharjo Km. 4 Kampus II Universitas Muslim Indonesia Makassar \\ m.syarif_nuh@yahoo.co.id
}

\begin{abstract}
In issuing Perppu, president's power seems to be "power full", it can not get any intervention from any other institution until the trial in DPR decides whether the Perppu is approved or rejected. This research raises some problems; first, what is the measurement or basic of forming Perppu by President? Second, what is the substance and content of the state of emergency that leads the forced crisis? The research method is based on primary and secondary law material, and it is done through literature study and it used juridical approach method. The research result concludes, first, the measurement or basic of forming Perppu by president is based on the condition or event that is extraordinary (abnormal) from a state, in the form of the state of emergency. Second, the substance or content of the state of emergency that leads the forced crisis contains of three elements, which are, first, the element of dangerous threat; second, the element of reasonable necessity; and third, the element of limited time.
\end{abstract}

Key words : State constitution, state of emergency, president's power

\begin{abstract}
Abstrak
Dalam mengeluarkan Perppu kekuasaan Presiden seolah "power full", tidak dapat diintervensi oleh lembaga manapun sampai tiba masanya persidangan di DPR menentukan apakah Perppu tersebut disetujui ataukah ditolak. Penelitian ini mengangkat permasalahan, pertama, apakah ukuran atau dasar pembentukan Perppu oleh Presiden? Kedua, apakah hakekat atau kandungan dari keadaan darurat negara (state of emergency) yang menimbulkan kegentingan yang memaksa? Metode penelitian didasarkan pada bahan hukum primer dan sekunder, dilakukan melalui studi pustaka dan menggunakan metode pendekatan yuridis. Hasil penelitian menyimpulkan, pertama, ukuran atau dasar pembentukan Perppu oleh Presiden didasarkan pada keadaan atau peristiwa yang sangat luar biasa (tidak normal) dari suatu negara yang berwujud berupa keadaan darurat negara (state of emergency). Kedua, hakekat atau kandungan dari keadaan darurat negara (state of emergency) yang menimbulkan kegentingan yang memaksa terdiri atas 3 (tiga) unsur, yaitu pertama, unsur adanya ancaman yang membahayakan (dangerous threat); kedua, unsur adanya kebutuhan yang mengharuskan (reasonable neccesity), dan ketiga, unsur adanya keterbatasan waktu (limited time) yang tersedia.
\end{abstract}

Kata kunci : Negara hukum, darurat negara, kekuasaan presiden. 


\section{Pendahuluan}

Negara Indonesia adalah negara hukum. Hal ini dinyatakan secara tegas di dalam Pasal 1 ayat (3) Undang-Undang Dasar Negara Republik Indonesia 1945 (selanjutnya disingkat UUD 1945) pasca amandemen. Sebagai negara hukum maka hukum harus dipahami sebagai satu kesatuan sistem yang terdiri dari elemenelemen kelembagaan (institusional), kaedah aturan (instrumental) dan perilaku para subyek hukum (elemen subyektif dan cultural). Ketiga elemen sistem hukum tersebut mencakup; kegiatan pembuatan hukum (law making), kegiatan pelaksanaan hukum atau penerapan hukum (law administration) dan kegiatan peradilan atas pelanggaran hukum (law adjudicating) atau yang biasa disebut dengan penegakan hukum dalam arti sempit (law enforcement). ${ }^{1}$

Indonesia sebagai negara hukum modern (welfare state) dalam rangka mewujudkan tujuan negara yakni memberikan kesejahteraan bagi masyarakatnya dan melindungi hak-hak asasi warga negaranya, harus menganut prinsip utama atau asas pokok yang terdiri atas asas legalitas, asas pengakuan dan perlindungan hak asasi manusia, asas pembagian kekuasaan negara, asas peradilan yang bebas dan tidak memihak, asas kedaulatan rakyat, asas demokrasi dan asas konstitusional. ${ }^{2}$

Makna atau nilai dari asas negara hukum tersebut adalah bahwa hukum merupakan sumber tertinggi (supremasi) dalam mengatur dan menentukan mekanisme hubungan hukum antara negara dan masyarakat, maupun antara anggota atau kelompok masyarakat yang satu dengan yang lainnya dalam mewujudkan tujuannya.

Pemerintah (bestuur) selaku pelaksana kebijakan politik negara mempunyai wewenang sebagaimana diberikan oleh peraturan perundang-undangan yang berlaku atau berdasarkan pada asas legalitas untuk mengendalikan pemerintahan, memimpin atau mengatur warganegaranya, memberi petunjuk, menggerakkan potensi, memberi arah, mengkoordinasikan kegiatan, mengawasi, mendorong dan melindungi masyarakatnya. ${ }^{3}$

${ }^{1}$ Jimly Asshiddiqie, Konstitusi dan Ketatanegaraan Indonesia Kontemporer, Penerbit The Biography Institute, Jakarta, 2007, hlm. 13 .

${ }^{2}$ Imran Juhaefah, Hal Ihwal Kegentingan Yang Memaksa Sebagai Landasan Pembentukan Peraturan Pemerintah Pengganti Undang-Undang, Disertasi, Pascasarjana Universitas Muslim Indonesia, Makassar, 2011, hlm. 2.

${ }^{3}$ Muin Fahmal, Peran Asas-asas Umum Pemerintahan Yang Layak Dalam Mewujudkan Pemerintahan Yang Bersih, Penerbit Kreasi Total Media, Yokyakarta, 2008, hlm. 100. 
Negara hukum modern cenderung untuk menjadi negara hukum yang progresif bilamana dilihat dari inisiatif untuk mewujudkan kesejahteraan umum yang datangnya selalu dari pihak negara (pemerintah) artinya dalam rangka mewujudkan kesejahteraan umum maka negara akan selalu aktif mengambil inisiatif untuk bertindak, bukan rakyat yang harus "meminta-minta" untuk dilayani oleh negara. Di sinilah gambaran tentang negara hukum Indonesia yang dicita-citakan. ${ }^{4}$ Pada tipe negara kesejahteraan modern seperti Indonesia ini maka pemerintah (bestuur) diberi kewajiban untuk turut serta dan aktif dalam pergaulan sosial ekonomi rakyatnya demi terwujudnya kesejahteraan bersama. Dengan demikian pemerintah atau administrasi negara (bestuur) memerlukan ruang gerak yang lebih bebas agar dapat bertindak cepat, tepat dan berfaedah atas inisiatif sendiri terhadap sesuatu yang peraturannya belum dibuat oleh pembuat undang-undang atau yang telah dibuat tetapi peraturannya tidak konkrit. ${ }^{5}$

Dalam praktik penyelenggaraan negara atau pemerintahan sering terjadi halhal yang tidak normal dalam menata kehidupan kenegaraan, di mana sistem hukum yang biasa digunakan tidak mampu mengakomodasi kepentingan negara atau masyarakat sehingga memerlukan pengaturan tersendiri untuk menggerakkan fungsi-fungsi negara agar dapat berjalan secara efektif guna menjamin penghormatan kepada negara dan pemenuhan hak-hak dasar warga negara. Dengan demikian maka penggunaan perangkat hukum biasa sejak semula haruslah mengantisipasi berbagai kemungkinan keadaan yang bersifat tidak normal agar negara dapat menjamin kelangsungan hidup berbangsa dan bernegara.

Untuk mengantisipasi keadaan tersebut, maka di Indonesia secara konstitusional telah diletakkan pengaturannya dalam Pasal 22 UUD 1945, sebagai berikut: (1) dalam hal ihwal kegentingan yang memaksa, Presiden berhak menetapkan Peraturan Pemerintah Pengganti Undang-Undang; (2) peraturan Pemerintah harus mendapat persetujuan Dewan Perwakilan Rakyat dalam persidangan berikut; (3) jika tidak mendapat persetujuan maka Peraturan Pemerintah itu harus dicabut.

Ketentuan sebagaimana dimaksud dalam ayat (1) tersebut di atas sangat diperlukan agar keselamatan negara dapat dijamin oleh pemerintah, yang memaksa pemerintah untuk bertindak cepat dan tepat. Meskipun demikian pemerintah tidaklah

${ }^{4}$ Satjipto Rahardjo, Negara Hukum Yang Membahagiakan Rakyatnya, Penerbit Genta Press, Yogyakarta, 2008, hlm. 118.

${ }^{5}$ Muin Fahmal, Op.Cit., hlm. 61. 
bebas membentuk Peraturan Pemerintah Pengganti Undang-Undang (Perppu) karena pemerintah tetap tidak terlepas dari pengawasan Dewan Perwakilan Rakyat.

Permasalahan yang muncul, dan seringkali menjadi bahan perdebatan di sejumlah kalangan ahli hukum maupun politik adalah parameter dari suatu keadaan yang dapat dikualifikasi sebagai "kegentingan yang memaksa". Beberapa Perppu yang pernah dikeluarkan oleh Presiden yakni Perppu No. 4 Tahun 2009 tentang Perubahan Atas Undang-Undang Nomor 30 Tahun 2002 tentang Komisi Pemberantasan Tindak Pidana Korupsi dan Perppu No. 4 Tahun 2008 tentang Jaring Pengaman Sistem Keuangan (JPSK), juga menimbulkan polemik di masyarakat. Dalam mengeluarkan Perppu kekuasaan Presiden seolah "power full", tidak dapat diintervensi oleh lembaga manapun sampai tiba masanya persidangan di DPR menentukan apakah Perppu tersebut disetujui atau ditolak. Presiden memiliki otoritas penuh untuk menilai dan menentukan suatu keadaan untuk dinyatakan dalam "kegentingan yang memaksa" atau tidak, sehingga perlu dikeluarkan Perppu.

\section{Rumusan Masalah}

Dari uraian di atas dirumuskan permasalahan yang akan diteliti sebagai berikut. Pertama, apakah ukuran atau dasar pembentukan Perppu oleh Presiden? Kedua, apakah hakekat atau kandungan dari keadaan darurat negara (state of emergency) yang menimbulkan kegentingan yang memaksa?

\section{Tujuan Penelitian}

Penelitian ini bertujuan untuk menganalisis ukuran atau dasar pembentukan Perppu oleh Presiden, serta hakekat atau kandungan dari keadaan darurat negara (state of emergency) yang menimbulkan kegentingan yang memaksa.

\section{Metode Penelitian}

Metode penelitian yang digunakan dalam penelitian ini adalah yuridis normatif, yaitu penelitian yang dalam pengkajiannya dengan mengacu dan mendasarkan pada norma-norma dan kaidah-kaidah hukum, peraturan perundang-undangan yang berlaku, teori-teori dan doktrin hukum, yurisprudensi, dan bahan-bahan kepustakaan lainnya yang relevan dengan topik penelitian. 
Pengumpulan bahan hukum dilakukan dengan studi pustaka yakni melalui pengkajian terhadap UUD Negara Republik Indonesia Tahun 1945 dan berbagai pustaka yang relevan dengan objek penelitian.

Pendekatan yang digunakan dalam penelitian ini adalah pendekatan yuridis, yakni menganalisis permasalahan hakekat keadaan darurat negara (state ofemergency) sebagai dasar pembentukan Perppu dari sudut pandang hukum dan pengaruhnya terhadap sistem ketatanegaraan Indonesia.

Dalam penelitian ini, data yang terkumpul dianalisis secara kualitatif. Pengolahan bahan hukum pada hakekatnya merupakan kegiatan untuk mengadakan sistematisasi terhadap bahan-bahan hukum. Sistematisasi berarti membuat klasifikasi terhadap bahan-bahan hukum tersebut untuk memudahkan pekerjaan analisis dan konstruksi. Bahan hukum yang sudah disistematisasi kemudian dianalisis secara kualitatif.

\section{Hasil dan Pembahasan}

\section{Hakekat Keadaan Darurat Negara}

Di Indonesia, perihal keadaan bahaya dan hal ihwal kegentingan yang memaksa sebagai dasar dari tindakan pemerintah untuk membentuk Perppu dalam rangka penyelamatan kepentingan bangsa dan negara, dapat ditemukan landasan hukumnya dalam Pasal 12 dan Pasal 22 UUD 1945. Pasal 12 menegaskan bahwa "Presiden menyatakan keadaan bahaya, syarat-syarat dan akibatnya keadaan bahaya ditetapkan dengan undang-undang". Pasal 22 menegaskan bahwa "dalam hal ihwal kegentingan yang memaksa Presiden menetapkan peraturan pemerintah pengganti undang-undang".

Berdasarkan ketentuan tersebut di atas, maka dapat diketahui adanya 2 (dua) kategori dari adanya keadaan yang tidak biasanya (luar biasa) dari negara atau keadaan darurat negara (state of emergency) yakni Pertama, keadaan bahaya, dan Kedua, hal ihwal kegentingan yang memaksa. Kedua kategori tersebut mempunyai makna yang sama sebagai keadaan darurat negara (state of emergency), namun keduanya mempunyai perbedaan pada penekanannya yakni istilah keadaan bahaya lebih menekankan pada strukturnya (faktor eksternal) sedangkan dalam hal ihwal kegentingan yang memaksa lebih menekankan pada isinya (faktor internal). 
Penggunaan kedua pasal tersebut sangat berbeda yakni Pasal 12 UUD 1945 lebih berfokus pada kewenangan Presiden selaku kepala negara untuk menyelamatkan bangsa dan negara dari gangguan luar negara, sedangkan penggunaan Pasal 22 UUD 1945 berada pada ranah (domain) pengaturan yaitu berkenaan dengan kewenangan Presiden untuk menetapkan Perppu. Dengan demikian lebih menekankan dari aspek internal negara berupa kebutuhan hukum yang bersifat mendesak. ${ }^{6}$ Itulah sebabnya maka apabila dicermati ketentuan UUD 1945 maka terdapat 3 (tiga) unsur penting secara bersama-sama (kumulatif) yang membentuk pengertian keadaan darurat bagi negara (state of emergency) yang menimbulkan kegentingan yang memaksa, yaitu: pertama, unsur adanya ancaman yang membahayakan (dangerous threat); kedua, unsur adanya kebutuhan yang mengharuskan (reasonable neccesity), dan ketiga, unsur adanya keterbatasan waktu (limited time) yang tersedia. ${ }^{7}$

Dalam praktiknya di Indonesia berbagai varian dibentuknya Perppu tidak memenuhi unsur-unsur keadaan darurat negara (state of emergency) secara kumulatif sebagaimana dikemukakan di atas sehingga dipertanyakan esensinya apakah pembentukan Perppu yang tidak memenuhi ketiga unsur tersebut secara bersamaan benar-benar sesuai dengan amanah UUD 1945 atau untuk kepentingan bangsa dan negara atau hanya untuk kepentingan Presiden dan kroninya atau untuk kepentingan sekelompok golongan saja.

Hal pembentukan Perppu dengan tujuan untuk kepentingan Presiden dan kroninya atau hanya untuk kepentingan segelintir golongan saja memang bisa terjadi, sebab sebagaimana dikatakan oleh Imran Juhaefah, ${ }^{8}$ dalam ketentuan UUD 1945 perihal keadaan bahaya dan hal ihwal kegentingan yang memaksa sebagai suatu keadaan darurat negara (state of emergency) tidak ditemukan landasan hukumnya yang tepat. Lebih lanjut dikatakan bahwa secara konstitusional berkenaan hak Presiden untuk memberlakukan keadaan darurat sebagaimana diatur dalam Pasal 12 dan Pasal 22 UUD 1945, apakah yang dimaksud dengan keadaan bahaya dan kegentingan yang memaksa dan dalam keadaan bagaimana sehingga suatu keadaan bahaya dan kegentingan yang memaksa dapat dikualifisir sebagai keadaan darurat negara, hal ini tidak ditemukan dalam rumusan pasal-pasal dalam UUDNRI $1945 .{ }^{9}$

\footnotetext{
${ }^{6}$ Imran Juhaefah, Op.Cit., hlm. 11-12.

${ }^{7}$ Jimly Asshiddiqie, Hukum Tata Negara Darurat, Penerbit PT. Rajawali Grafindo Persada, Jakarta, 2007, hlm. 207.

${ }^{8}$ Imran Juhaefah, Op. Cit., hlm. 10.

${ }^{9}$ Ibid., hlm. 18.
} 
Berdasarkan uraian di atas, maka Presiden baik selaku kepala negara maupun selaku kepala pemerintahan mempunyai kewenangan konstitusional dalam menetapkan Perppu untuk mengatur hal-hal yang diperlukan dalam rangka penyelamatan bangsa dan negara. Materi atau isi yang dimuat dalam Perppu tentunya tergantung pada kebutuhan nyata yang dihadapi negara (the actual legal necessity). Bahkan ketentuan-ketentuan tertentu yang menyangkut perlindungan hak asasi manusia yang dijamin dalam UUDNRI 1945 tersebut dapat saja ditentukan lain dalam Perppu sepanjang hal itu dimaksudkan untuk mengatasi keadaan darurat negara guna melindungi kepentingan bangsa dan negara. Tentu saja Perppu tetap terbuka dan tunduk kepada pengujian oleh Pengadilan (Judicial Review) sehingga konstitusionalnya baik secara materiil maupun formiil tetap dapat dipertanggungjawabkan secara hukum. ${ }^{10}$

Sependapat dengan Jimly Asshiddiqie, Ni'matul Huda ${ }^{11}$ menyatakan, bahwa Perppu meskipun lahir dari suatu keadaan "kegentingan yang memaksa", tetap harus dapat diuji oleh lembaga peradilan. Namun, UUD 1945 tidak menentukan secara tegas lembaga mana yang berwenang menguji Perppu. Dari ketentuan UUD 1945 maupun dalam UU No. 24 Tahun 2003 jo UU No. 4 Tahun 2004 jo UU No. 5 Tahun 2004 jo UU No. 3 Tahun 2009, tidak diketemukan norma yang secara tegas mengatur kewenangan lembaga judisial untuk menguji Perppu. Belakangan diketahui ternyata Mahkamah Konstitusi telah menguji Perppu. Di dalam Putusan MK No. 138/PUU-VII/2009 dan No. 145/PUU-VII/2009 Mahkamah mendalilkan sebagai berikut Perppu melahirkan norma hukum dan sebagai norma hukum baru akan dapat menimbulkan: (a) status hukum baru, (b) hubungan hukum baru, dan (c) akibat hukum baru. Norma hukum tersebut lahir sejak Perppu disahkan dan nasib dari norma hukum tersebut tergantung kepada persetujuan DPR untuk menerima atau menolak norma hukum Perppu, namun demikian sebelum adanya pendapat DPR untuk menolak atau menyetujui Perppu, norma hukum tersebut adalah sah dan berlaku seperti undang-undang. Oleh karena dapat menimbulkan norma hukum yang kekuatan mengikatnya sama dengan undang-undang, maka terhadap norma yang terdapat dalam Perppu tersebut Mahkamah dapat menguji apakah bertentangan secara materiil dengan UUD 1945. Dengan demikian,

\footnotetext{
${ }^{10}$ Jimly Asshiddiqie, Hukum Tata Negara ..., Op.Cit, hlm. 282.

${ }^{11}$ Ni'matul Huda, Pengujian Perppu oleh Mahkamah Konstitusi, Jurnal Konstitusi, Mahkamah Konstitusi RI, Volume 7 Nomor 5, Oktober 2010, hlm. 80-88.
} 
Mahkamah berwenang untuk menguji Perppu terhadap UUD 1945 sebelum adanya penolakan atau persetujuan oleh DPR, dan setelah adanya persetujuan DPR karena Perpu tersebut telah menjadi undang-undang.

Selain unsur-unsur di atas, suatu keadaan darurat negara (state of emergency) harus pula mendasarkan diri pada prinsip proporsionalitas (the principle of proporsionality) yang dikenal dalam hukum internasional. Prinsip ini dianggap sebagai the crus of the self defence doctrine atau inti dari doktrin Self Defence. Secara inheren prinsip proporsionalitas dianggap memberikan standar mengenai kewajaran (standard of reasonabeleness), sehingga kriteria untuk menentukan adanya necessity menjadi lebih jelas, kebutuhan yang dirumuskan sebagai alasan pembenar untuk melakukan tindakan yang bersifat darurat bersifat proporsional, wajar atau setimpal sehingga tindakan dimaksud tidak boleh melebihi kewajaran atau kesetimpalan yang menjadi dasar pembenaran bagi dilakukannya tindakan itu sendiri. ${ }^{12}$

Di Indonesia dalam kenyataannya banyak pembentukan Perppu dilakukan tidak mempertimbangkan unsur-unsur keadaan darurat negara secara kumulatif dan prinsip-prinsip proporsionalitas di atas, tetapi hanya mendasarkan pada satu unsur keadaan darurat negara saja, misalnya: a. pembentukan Perppu Nomor 1 Tahun 2002 tentang Pemberantasan Tindak Pidana Terorisme, hanya didasarkan pada unsur ancaman yang membahayakan (dangerous threat) saja. Hal ini dapat diketahui dari penjelasan umumnya yang menegaskan bahwa penggunaan Perppu ini untuk mengatur pemberantasan tindak pidana terorisme yang didasarkan pada pertimbangan bahwa terjadinya terorisme diberbagai tempat telah menimbulkan kerugian baik materiil maupun immateriil serta menimbulkan ketidakamanan bagi masyarakat, sehingga mendesak untuk dikeluarkan Perppu guna dapat segera diciptakan suasana yang kondusif bagi pemeliharaan ketertiban dan keamanan tanpa meninggalkan prinsip-prinsip negara hukum. ${ }^{13}$

Demikian juga pembentukan Perppu Nomor 3 Tahun 2009 tentang Perubahan atas Undang-Undang Nomor 9 Tahun 1992 tentang Keimigrasian, hanya didasarkan pada unsur kebutuhan yang mengharuskan (reasonableneccesity), di mana kebijakan Pemerintah Arab Saudi yang menetapkan bahwa mulai tahun 1430 Hijriah jemaah haji dari seluruh negara termasuk Indonesia harus menggunakan paspor biasa (ordinary passport) yang

\footnotetext{
${ }^{12}$ Jimly Asshiddiqie, Loc. Cit.

${ }^{13}$ Febriansyah, dalam Jurnal Legislasi Indonesia, Vol. 6 No. 4, Desember 2009, hlm. 672.
} 
berlaku secara internasional. Penggunaan paspor biasa (ordinary passport) ini dijadikan sebagai dasar "kegentingan yang memaksa" sehingga Indonesia perlu melakukan upaya yang bersifat segera untuk menjamin tersedianya paspor dimaksud agar penyelenggaraan ibadah haji tetap dapat dilaksanakan pada tahun 1430 Hijriah tersebut. ${ }^{14}$

Pembentukan Perppu Nomor 1 Tahun 2006 tentang Perubahan Kedua atas Undang-Undang Nomor 12 Tahun 2003 tentang Pemilihan Umum Anggota Dewan Perwakilan Rakyat, Dewan Perwakilan Daerah dan Dewan Perwakilan Rakyat Daerah, hanya didasarkan pada unsur keterbatasan waktu (limited time) yang tersedia. Perppu ini mengatur bahwa anggota Komisi Pemilihan Umum (KPU) yang diangkat berdasarkan Undang-Undang Nomor 4 Tahun 2000 tentang Perubahan UndangUndang Nomor 3 Tahun 1999 tentang Pemilihan Umum sebagaimana telah disesuaikan pula dengan Undang-Undang Nomor 12 Tahun 2003 tetap melaksanakan tugasnya sampai dengan terbentuknya penyelenggaraan pemilihan umum yang baru. Hal ini mengingat Dewan Perwakilan Rakyat sedang mempersiapkan rancangan undang-undang tentang penyelenggaraan pemilihan umum untuk menggantikan ketentuan yang berlaku saat itu yakni Undang-Undang Nomor 12 Tahun 2003. Berdasarkan pertimbangan tersebut, Presiden berpendapat bahwa syarat hal ihwal kegentingan yang memaksa telah terpenuhi untuk menetapkan Perppu tentang perubahan atas Undang-Undang Nomor 12 Tahun 2003. ${ }^{15}$

Kewenangan pembentukan perundang-undangan yang dimiliki oleh institusi atau pejabat dapat diperoleh melalui atribusi dan delegasi kewenangan. Atribusi kekuasaan (atributie van rechtsmacht) khusus kekuasaan membentuk peraturan perundang-undangan (atributie van wet wegeven demacht) sering diartikan sebagai pemberian kewenangan kepada badan atau pejabat negara tertentu yang diberikan oleh pembentuk undang undang dasar maupun oleh pembentuk undang-undang. Pemberian wewenang dimaksud melahirkan suatu kewenangan serta tanggung jawab yang mandiri. Jadi ada suatu orginal power (orginaire van macht) yang kemudian melahirkan suatu orginal power legislation (orginaire wetgeven demacht). Jelasnya, dalam kewenangan atribusi terdapat suatu kewenangan baru. ${ }^{16}$

\footnotetext{
${ }^{14}$ Ibid.

${ }^{15}$ Ibid., hlm. 673.

${ }^{16}$ Ranggawaijaya, dalam Pantja Astawa dan Suprin Na'a, Dinamika Hukum dan Ilmu Perundang-undangan di Indonesia, Edisi Pertama, Cetakan Pertama, Alumni, Bandung, 2008, hlm. 53.
} 
Kewenangan pembentukan Perppu menurut UUD 1945 hanya diberikan kepada Presiden, termasuk kewenangan untuk menetapkan ada atau terjadinya hal keadaan darurat negara. Kewenangan ini sifatnya atributif (atributie van wet wegeven demacht) yang juga melahirkan tanggungjawab kepada Presiden. Karena itu, kewenangan tersebut bersifat subjektif artinya hak untuk menetapkan Perppu didasarkan atas penilaian subjektif dari Presiden sendiri mengenai adanya keadaan darurat negara (state of emergency) yang menimbulkan kegentingan yang memaksa. Muh. Yamin berpendapat bahwa ada tidaknya keadaan mendesak itu penilaiannya (evaluasinya) menurut kebijaksanaan pemerintah. ${ }^{17}$ Hal ini berarti bahwa keadaan mendesak dapat saja sewaktu-waktu timbul jika pemerintah menilai suatu keadaan telah berada dalam suasana genting dan memaksa. Penilaian mengenai terjadinya keadaan darurat negara yang menimbulkan kegentingan yang memaksa secara objektif baru terjadi pada saat Perppu itu dibenarkan atau disahkan oleh DPR berdasarkan ketentuan Pasal 22 ayat (2) UUD 1945, ${ }^{18}$ yang oleh Wirjono Prodjodikoro diungkapkan bahwa keadaan mendesak terdapat pada saat DPR sedang reses. ${ }^{19}$

Walaupun menurut UUD 1945 kewenangan membentuk Perppu bersifat kewenangan subjektif Presiden namun demi penyelamatan bangsa dan negara, bilamana ditinjau dari sisi filosofisnya maka idealnya pembentukan Perppu itu haruslah memenuhi unsur-unsur keadaan darurat negara (state of emergency) secara kumulatif dan prinsip proporsionalitas yang mengandung sifat kewajaran. Selain itu, juga harus memenuhi persyaratan sebagaimana yang ditentukan dalam UndangUndang Nomor 10 Tahun 2004 tentang Pembentukan Peraturan Perundangundangan karena Perppu ini merupakan salah satu bentuk peraturan perundangundangan yang dimaksudkan dalam Undang-Undang Nomor 10 Tahun 2004 tersebut.

Dalam ketentuan Bab II Undang-Undang Nomor 10 Tahun 2004 dikemukakan bahwa asas-asas peraturan perundang-undangan dapat dikelompokkan menjadi 2 yakni pertama, asas yang berkaitan dengan pembentukan peraturan perundangundangan, dan kedua, asas yang berkaitan dengan materi muatan peraturan perundang-undangan.

\footnotetext{
${ }^{17}$ Wirjono Prodjodikoro, Asas Hukum Tata Negara Indonesia, Jakarta, 1970, hlm. 23.

${ }^{18}$ Jimly Asshiddiqie, Hukum Tata Negara ..., Op.Cit., hlm. 23.

${ }^{19}$ Wirjono Prodjodikoro, Op.Cit., hlm. 23.

${ }^{20}$ B. Hestu Cipto Handoyo, Prinsip-prinsip Legal Drafting dan Desain Naskah Akademik, Yokyakarta, Penerbit Universitas Atmajaya Yogyakarta, 2008, hlm. 78.
} 
Asas yang berkaitan dengan pembentukan peraturan perundang-undangan terdapat di dalam Pasal 5 Undang-Undang Nomor 10 Tahun 2004 yang menegaskan bahwa asas pembentukan peraturan perundang-undangan yang baik, ${ }^{20}$ meliputi: a. asas kejelasan tujuan adalah bahwa setiap pembentukan peraturan perundangundangan harus mempunyai tujuan yang jelas yang hendak dicapai; $b$. asas kelembagaan atau organ pembentuk yang tepat, bahwa setiap jenis peraturan perundang-undangan harus dibuat oleh lembaga/pejabat pembentuk peraturan perundang-undangan yang berwenang. Peraturan perundang-undangan tersebut dapat dibatalkan atau batal demi hukum apabila dibuat oleh lembaga/pejabat yang tidak berwenang; c. asas kesesuaian antara jenis dan materi muatan, bahwa dalam pembentukan peraturan perundang-undangan harus benar-benar memperhatikan materi muatan yang tepat dengan jenis peraturan perundang-undangannya; $d$. asas dapat dilaksanakan, adalah bahwa setiap pembentukan peraturan perundangundangan harus memperhitungkan efektivitas peraturan perundang-undangan tersebut di dalam masyarakat, baik secara filosofis, yuridis maupun sosiologis; e. asas kedayagunaan dan kehasilgunaan, adalah bahwa setiap peraturan perundangundangan dibuat karena memang benar-benar dibutuhkan dan bermanfaat dalam mengatur kehidupan bermasyarakat, berbangsa dan bernegara; f.asas kejelasan rumusan adalah bahwa setiap peraturan perundang-undangan harus memenuhi persyaratan teknis penyusunan peraturan perundang-undangan, sistimatik dan pilihan kata atau terminologi serta bahasa hukumnya jelas dan mudah dimengerti, sehingga tidak menimbulkan berbagai macam interpretasi dalam pelaksanaannya; g. asas keterbukaan adalah bahwa dalam proses pembentukan peraturan perundang-undangan mulai dari perencanaan, persiapan, penyusunan dan pembahasan bersifat transparan dan terbuka, dengan demikian seluruh masyarakat mempunyai kesempatan yang seluas-luasnya untuk memberikan masukan dalam proses pembentukan peraturan perundang-undangan. ${ }^{21}$

Asas yang berkaitan dengan materi muatan peraturan perundang-undangan ditegaskan dalam ketentuan Pasal 6 ayat (1) Undang-Undang Nomor 10 Tahun 2004, yakni: a. asas pengayoman, artinya setiap materi muatan peraturan perundangundangan harus berfungsi memberikan perlindungan dalam rangka menciptakan ketentraman masyarakat; b. asas kemanusiaan, artinya setiap materi muatan

${ }^{21}$ Penjelasan Pasal 5 Undang-Undang Nomor 10 Tahun 2004 tentang Pembentukan Peraturan Perundangundangan. 
peraturan perundang-undangan harus mencerminkan perlindungan dan penghormatan hak-hak asasi manusia serta harkat dan martabat setiap warga negara dan penduduk Indonesia secara proporsional; c. asas kebangsaan, artinya setiap materi muatan peraturan perundang-undangan harus mencerminkan sifat dan watak bangsa Indonesia yang pluralistic (kebhinekaan) dengan tetap menjaga prinsip Negara Kesatuan Republik Indonesia; d. asas kekeluargaan, artinya setiap materi muatan peraturan perundang-undangan harus mencerminkan musyawarah untuk mencapai mufakat dalam setiap pengambilan keputusan; e. asas kenusantaraan artinya setiap peraturan perundang-undangan senantiasa memperhatikan kepentingan seluruh wilayah Indonesia dan materi muatan peraturan perundangundangan yang dibuat di daerah merupakan bagian dari sistem hukum nasional yang berdasarkan Pancasila; $f$. asas bhineka tunggal ika, artinya setiap materi muatan peraturan perundang-undangan harus memperhatikan keragaman penduduk, agama, suku dan golongan, kondisi khusus daerah, dan budaya khususnya yang menyangkut masalah-masalah sensitif dalam kehidupan bermasyarakat, berbangsa dan bernegara; g. asas keadilan, artinya setiap materi muatan peraturan perundangundangan harus mencerminkan keadilan secara proporsional bagi setiap warga tanpa kecuali; h. asas kesamaan kedudukan dalam hukum dan pemerintahan, artinya setiap materi muatan peraturan perundang-undangan tidak boleh berisi hal-hal yang bersifat membedakan berdasarkan latar belakang antara lain, agama, suku, ras, golongan, gender, atau status sosial; i. asas ketertiban dan kepastian hukum, artinya setiap materi muatan peraturan perundang-undangan harus dapat menimbulkan ketertiban dalam masyarakat melalui jaminan adanya kepastian hukum; j. asas keseimbangan, keserasian, dan keselarasan artinya setiap materi muatan peraturan perundangundangan harus mencerminkan keseimbangan, keserasian, dan keselarasan antara kepentingan individu dan masyarakat dengan kepentingan bangsa dan negara. ${ }^{22}$

Pemenuhan unsur-unsur, asas-asas atau prinsip-prinsip tersebut di atas penting karena Perppu setelah dibentuk oleh Presiden langsung diberlakukan dan mengikat secara umum tanpa menunggu persetujuan DPR sebelumnya. Perppu yang dibentuk oleh Presiden tersebut dalam keadaan negara kembali normal (pada sidang DPR berikutnya) harus diajukan ke DPR untuk mendapatkan persetujuan menjadi Undang-Undang ataupun sebaliknya dilakukan pencabutan bilamana DPR tidak menyetujui atau menolaknya.

${ }_{22}^{2}$ Penjelasan Pasal 6 Undang-Undang Nomor 10 Tahun 2004 tentang Pembentukan Peraturan Perundang-undangan. 
Perppu ini merupakan peraturan pemerintah (PP) yang menggantikan kedudukan undang-undang (UU), materi muatannya adalah sama dengan materi undang-undang. ${ }^{23}$ Pengganti undang-undang adalah bahwa materi muatan Perppu merupakan materi muatan undang-undang, dalam keadaan biasa (normal) materi muatan tersebut harus diatur dengan undang-undang. ${ }^{24}$

Berdasarkan uraian tersebut, maka dalam ketentuan Pasal 9 Undang-Undang Nomor 10 Tahun 2004 ditegaskan bahwa materi muatan Perppu sama dengan materi muatan undang-undang, karena memang Perppu adalah undang-undang yang dibentuk seperti Peraturan Pemerintah (PP).

Sebagai peraturan darurat, Perppu mengandung pembatasan-pembatasan; Pertama, Perppu hanya dikeluarkan dalam hal negara dalam keadaan darurat (hal ihwal kegentingan yang memaksa). Dalam praktik, hal ihwal kegentingan yang memaksa sering diartikan secara luas, tidak hanya terbatas pada keadaan yang mengandung suatu kegentingan atau ancaman, tetapi termasuk juga kebutuhan yang dipandang mendesak; Kedua, Perppu hanya berlaku untuk jangka waktu yang terbatas. Presiden paling lambat dalam masa sidang DPR berikutnya harus mengajukan Perppu ke DPR untuk memperoleh persetujuan. Apabila disetujui oleh DPR, maka Perppu berubah menjadi undang-undang, tetapi kalau tidak disetujui maka Perppu tersebut harus segera dicabut.

Pembatasan jangka waktu dan persetujuan DPR mengandung makna bahwa; pertama, kewenangan membuat Perppu memberikan kekuasaan luar biasa kepada Presiden, kekuasaan luar biasa ini harus dapat dikendalikan untuk menghindari penyalahgunaan kekuasaan dengan cara Presiden dalam masa sidang DPR berikutnya harus mengajukan Perppu ini ke DPR untuk memperoleh persetujuan, kedua, Perppu mencerminkan suatu keadaan darurat, dimana keadaan darurat ini merupakan pembenaran untuk menyimpangi prinsip-prinsip negara hukum. Dengan pengajuan Perppu secepat mungkin kepada DPR berarti secepat mungkin pula pengembalian negara pada keadaan normal yang dapat menjamin pelaksanaan prinsip-prinsip negara hukum.

Perppu juga merupakan peraturan perundang-undangan yang bersifat darurat, oleh karena itu dalam Konstitusi Republik Indonesia Serikat 1949 (KRIS)

\footnotetext{
${ }^{23}$ Indriati Soeprapto, Ilmu Perundang-undangan, Dasar-dasar dan Pembentukannya, Kanisus, Yogyakarta, 1998, hlm. 131.

${ }^{24}$ Bagir Manan, Dasar-dasar Perundang-Undangan Indonesia, Ind-hill.Co, Jakarta, 1992, hlm. 50.

${ }^{25}$ Jimly Asshiddiqie, dalam Panca Astawa, ..., Op.Cit., hlm. 62
} 
dan Undang-Undang Dasar Sementara Tahun 1950 (UUDS) disebut Undang-Undang Darurat. Istilah Undang-Undang Darurat menggambarkan pengertian sebagai Emergency Law (Emergenci Lagislation). ${ }^{25}$ Istilah Perppu itu sendiri ditemukan dalam Pasal 22 ayat (1) UUD 1945 (sebelum amandemen) yang menegaskan bahwa "dalam hal ihwal kegentingan yang memaksa, Presiden berhak menetapkan Perppu". Kemudian dalam ketentuan Pasal 1 butir 4 Undang-Undang Nomor 10 Tahun 2004, ditegaskan bahwa "Perppu adalah peraturan perundang-undangan yang ditetapkan oleh Presiden dalam hal ihwal kegentingan yang memaksa.

Salah satu substansi yang tidak ikut dirubah dalam proses amandemen UUDNRI 1945 adalah ketentuan mengenai Perppu sehingga eksistensi Perppu sebagai salah satu jenis peraturan perundang-undangan di Indonesia secara esensial selalu diakui. Dengan demikian, dapat diasumsikan bahwa eksistensi Perppu dalam sistem ketatanegaraan Indonesia masih tetap diperlukan sebagai konsekuensi logis dianutnya sistem pemerintahan Presidensil.

Pasal 24 Undang-Undang Nomor 10 Tahun 2004 mengatur bahwa ketentuan lebih lanjut mengenai tata cara mempersiapkan rancangan Perppu ditindaklanjuti dengan Peraturan Presiden (Perpres). Perpres yang dimaksud adalah Perpres Nomor 68 Tahun 2005 tentang Tata Cara Mempersiapkan Rancangan Perppu.

Pasal 36 Perpres Nomor 68 Tahun 2005 menegaskan bahwa dalam hal ihwal kegentingan yang memaksa, Presiden memerintahkan penyusunan Perppu. Siapa yang diperintahkan oleh Presiden untuk menyusun Perppu, dalam Pasal 37 Perpres Nomor 68 Tahun 2005 ditegaskan bahwa yang diberi tugas menyusun Perppu adalah menteri yang tugas dan tanggungjawabnya meliputi materi yang akan diatur dalam Perppu tersebut.

Setelah Perppu ditetapkan oleh Presiden, maka menteri sebagaimana dimaksud dalam Pasal 37 Perpres Nomor 68 Tahun 2005 kembali diberi tugas menyusun rancangan undang-undang mengenai penetapan Perppu menjadi undang-undang. Rancangan undang-undang yang telah disetujui oleh Presiden disampaikan kepada DPR untuk dilakukan pembahasan.

Mengacu pada ketentuan di atas, maka eksistensi suatu Perppu tergantung pada ada atau tidaknya persetujuan DPR terhadap pembentukan Perppu menjadi undang-undang. Dalam hal DPR memberi persetujuan terhadap Perppu tersebut maka rancangan undang-undang tentang penetapan Perppu disahkan menjadi undang-undang, sebaliknya jika DPR menolak Perppu tersebut, maka Presiden 
mengajukan rancangan undang-undang tentang pencabutan Perppu tersebut yang dapat mengatur pula tentang segala akibat hukum dari penolakan tersebut.

\section{Keadaan Darurat sebagai Landasan Pembentukan Perppu di Indonesia}

Banyak kejadian atau peristiwa dalam suatu negara yang dapat menyebabkan peraturan perundang-undangan yang berlaku tidak mampu mengakomodasi kejadian atau peristiwa tersebut karena kejadian atau peristiwa tersebut merubah keadaan negara dari yang biasa (normal) menjadi negara dalam keadaan yang luar biasa (tidak normal) atau negara dalam keadaan darurat yang dapat menimbulkan kekacauan dan ancaman bagi bangsa dan negara.

Keadaan darurat mempunyai pengertian yang luas, ia dapat berwujud keadaan darurat militer atau keadaan darurat perang, keadaan darurat karena bencana alam, keadaan darurat administratif berupa keadaan darurat keuangan (financial emergency) atau keadaan darurat yang biasa disebut welfare emergency dan lain sebagainya.

Dalam keadaan-keadaan yang tidak biasa atau tidak normal tersebut berlaku norma-norma yang juga bersifat khusus yang memerlukan pengaturan tersendiri baik mengenai syarat-syaratnya, tata cara pemberlakuannya dan tata cara mengakhirinya, serta hal-hal yang dapat atau tidak dapat dilakukan oleh pemerintah dalam keadaan darurat tersebut agar tidak memberi kesempatan timbulnya penyalahgunaan wewenang yang bertentangan dengan undang-undang dasar. ${ }^{26}$

Pemberlakukan suatu keadaan darurat (state of emergency) di suatu negara yang menganut sistem pemerintahan presidensial sebagaimana halnya di Indonesia memberikan pembenaran kepada Presiden untuk mengambil tindakan yang diperlukan untuk mengatasi keadaan darurat tersebut dengan tetap memperhatikan peran DPR untuk; a. melakukan pengawasan yang ketat dalam menentukan adanya suatu keadaan darurat (recognizing an emergency); b. membentuk kekuasaan untuk mengatasi keadaan darurat itu (creating the powers to deal with it); c. memantau pelaksanaan kewenangan pemerintah (eksekutif) untuk mengatasi keadaan yang tidak normal tersebut; d. menyelidiki berbagai penyimpangan atau penyalahgunaan kewenangan dalam keadaaan darurat tersebut; e. apabila diperlukan menyatakan berakhirnya masa keadaan darurat atau meminta kepada Presiden untuk menyatakan mengakhiri keadaan darurat tersebut. ${ }^{27}$

\footnotetext{
${ }^{26}$ Jimly Asshiddiqie, Hukum Tata Negara ..., Op.Cit., hlm. 3

${ }^{27}$ Jimly Asshiddiqie, Ibid., hlm 80.
} 
Karena itu, keadaan darurat tidak selamanya bersifat militer atau keadaan darurat perang yang memberikan kewenangan kepada Presiden untuk mengambil tindakan yang cepat dan tepat untuk menyelamatkan bangsa dan negara.

Untuk pemberlakuan suatu keadaan darurat harus memenuhi syarat-syarat baik syarat materil maupun syarat formil. Syarat materil yakni harus ada lembaga negara baru yang berkaitan dengan keadaan darurat tersebut dan harus pula dilengkapi dengan kewenangan baru untuk bertindak dan syarat formilnya adalah bahwa lembaga negara yang baru tersebut harus bertindak berdasarkan peraturan perundang-undangan yang berlaku.

Dalam konteks negara Indonesia, beberapa syarat formil yang harus dipenuhi untuk pemberlakuan suatu keadaan darurat, adalah sebagai berikut: a. pernyataan atau deklarasi berlakunya keadaan darurat itu harus dituangkan dalam bentuk tertentu yaitu dengan Keputusan Presiden sedangkan pengaturan materil yang diperlukan dalam keadaan darurat tersebut dituangkan dalam bentuk Perppu sebagaimana dimaksud oleh UUDNRI 1945; b. pejabat yang secara konstitusional berwenang untuk menetapkan dan mengatur keadaan darurat itu hanya Presiden, bukan pejabat yang lain; c. Perpres (Peraturan Presiden) dan Perppu yang dimaksud di atas disahkan dan ditandatangani oleh Presiden serta diundangkan dalam lembaran negara sebagaimana mestinya; $d$. Perppu hendaknya menentukan dengan jelas ketentuan-ketentuan undang-undang apa saja yang dikesampingkan oleh berlakunya Perppu tersebut; e. Perpres yang dimaksud harus menentukan dengan jelas wilayah hukum berlakunya dalam wilayah Republik Indonesia, misalnya apakah Perppu itu berlaku untuk seluruh wilayah nasional atau hanya berlaku di daerah tertentu saja, seperti halnya di provinsi tertentu atau di kabupaten tertentu; f. Perppu dan Perpres tersebut harus pula menentukan dengan pasti lama berlakunya keadaan darurat tersebut. Jika pembatasan semacam itu tidak ditegaskan, berarti Keppres atau Perppu tersebut hanya berlaku selama masa persidangan DPR sampai dengan dibukanya kembali masa persidangan berikutnya sebagaimana dimaksud dalam Pasal 22 UUDNRI 1945; g. segera setelah diberlakukan Perppu harus diajukan kepada DPR untuk mendapatkan persetujuan sebagaimana mestinya. Jika dalam masa persidangan berikutnya DPR tidak atau belum menyatakan persetujuannya, maka Perppu harus dinyatakan dicabut oleh Presiden..$^{28}$ 
Setelah keadaan darurat diberlakukan, sepanjang diperlukan oleh penguasa keadaan darurat, maka penguasa keadaan darurat dapat menetapkan peraturanperaturan yang bersifat pelaksanaannya. Peraturan-peraturan yang diperlukan dalam keadaan darurat itu adalah peraturan-peraturan yang juga bersifat luar biasa, akan tetapi tidak semua bentuk dan jenis peraturan perundang-undangan yang berlaku sebelumnya dengan sendirinya menjadi tidak berlaku lagi. Ukuran yang harus dijadikan pegangan adalah apakah untuk bertindak secara cepat dan tepat dalam keadaan darurat itu, peraturan yang dimaksud memang tidak dapat lagi dijadikan acuan.

Sekiranya tindakan yang perlu diambil secara tepat dan tepat untuk mengatasi keadaan darurat terpaksa melanggar hukum, maka peraturan-peraturan yang perlu dilanggar itulah yang harus dirubah sebagaimana mestinya oleh peraturan yang ditetapkan oleh penguasa keadaan darurat yang bersangkutan. ${ }^{29}$

\section{Penutup}

Dari paparan di atas, dapat disimpulkan hal-hal sebagai berikut. Pertama, ukuran atau dasar pembentukan Perppu oleh Presiden didasarkan pada keadaan atau peristiwa yang sangat luar biasa (tidak normal) dari suatu negara yang berwujud berupa keadaan darurat negara (state of emergency). Kedua, hakekat atau kandungan dari keadaan darurat negara (state of emergency) yang menimbulkan kegentingan yang memaksa terdiri atas 3 (tiga) unsur, yaitu pertama, unsur adanya ancaman yang membahayakan (dangerous threat); kedua, unsur adanya kebutuhan yang mengharuskan (reasonable neccesity), dan ketiga, unsur adanya keterbatasan waktu (limited time) yang tersedia.

Dalam pandangan peneliti, idealnya Perppu hanya dapat dibentuk oleh Presiden apabila memenuhi ke tiga unsur keadaan darurat negara secara bersamaan tersebut, memenuhi prinsip atau asas proporsionalitas yang mengandung unsur kewajaran dan memenuhi syarat-syarat lainnya sebagaimana yang diatur dalam Undang-Undang Nomor 10 Tahun 2004 dan Keppres Nomor 68 Tahun 2005. Di samping itu, agar Presiden tidak menyalahgunakan wewenangnya membentuk Perppu dan agar Perppu menjamin adanya kepastian hukum, maka Perppu yang

${ }^{29}$ Ibid., hlm. 300. 
dibentuk tersebut harus segera diajukan kepada DPR dan segera dibahas oleh DPR pada masa sidang berikutnya untuk memperoleh persetujuan atau penolakan (legislative review).

\section{Daftar Pustaka}

Asshidiqie, Jimly, Konstitusi dan Ketatanegaraan Indonesia Kontemporer, The Biography Institue, Jakarta, 2007.

,Hukum Tata Negara Darurat, Penerbit PT Rajawali Grafindo Persada, Jakarta, 2007.

Fahmal, Muin, Peran Asas-asas Umum Pemerintahan yang Layak Dalam Mewujudkan Pemerintahan yang Bersih, Penerbit Kreasi Total Media, Yogyakarta, 2008.

Febriansyah, dalam Jurnal Legislasi Indonesia, Vol. 6 No. 4 Tahun 2009

Gde Pantja Astawa dan Suprin Na'a, I., Dinamika Hukum dan Ilmu Perundang-Undangan di Indonesia, Edisi Pertama, Cetakan Pertama, Alumni, Bandung, 2008.

Hestu Cipto Handoyo, B., Prinsip-Prinsip Legal Darfitng dan Desain Naskah Akademik, Universitas Atmajaya, Yogyakarta, 2008.

Huda, Ni'matul, Pengujian Perppu oleh Mahkamah Konstitusi, Jurnal Konstitusi, Mahkamah Konstitusi RI, Volume 7 Nomor 5, Oktober 2010.

Juhaefah, Imran, Hal Ikhwal Kegentingan Yang Memaksa sebagai Landasan Pembentukan Peraturan Pemerintah Pengganti Undang-undang, Disertasi, Pascasarjana Universitas Muslim Indonesia, 2011.

Manan, Bagir, Dasar-Dasar Konstitusional Peraturan Perundang-Undangan Nasional, Fakultas Hukum Universitas Andalas, Padang,1994.

Prodjodikoro, Wirjono, Asas Hukum Tata Negara Indonesia, Jakarta, 1970.

Rahardjo, Satjipto, Negara Hukum Yang Membahagiakan Rakyatnya, Penerbit Genta Press, Yogyakarta, 2008.

Soeprapto, Indrati, Maria Farida, Ilmu Perundang-Undangan, Dasar-dasar dan Pembentukannya, Kanisius, Yogyakarta, 1998. 